\title{
Exploration and Utilization of Plant Species Based on Social Culture (Hindu Religion Ceremony) in Tenganan Pegringingan Village, Karangasem Regency, Bali Province, Indonesia
}

\author{
Nyoman Wijana $^{1 *}$, Sanusi Mulyadiharja ${ }^{2}$, I Made Oka Riawan ${ }^{3}$ iD \\ ${ }^{1234}$ Lecturer in Department of Bilogy and Marine Fishery, Faculty of Math and Science, Universitas Pendidikan Ganesha, \\ Indonesia \\ *Corresponding author: wijana_1960@yahoo.com
}

\begin{abstract}
This research aims to find out (1) the plants that were used in religious ceremonies (Hinduism) in accordance with the Bali Aga Tenganan Pegringsingan culture. 2) the making process of the various means needed in religious ceremonies (Hinduism) related to the utilization of useful plant species in Bukit Kangin Forest, Tenganan Pegringsingan Village. The Research was explorative (vegetation) and socio-system (community) research. The populations of this research were ecosystem aspects and sociosystem aspects. The ecosystem aspects included all of the useful plant species in Bukit Kangin Forest of Tenganan Pegringsingan village. Meawhile, the sociosystem aspects included the village officials, the village public figures and the community of Tenganan Pegringsingan village. The ecosystem sample (the vegetation) used in this research included the plant species in the forest of Tenganan Pegringsingan Village covered by the $1 \mathrm{x} 1 \mathrm{~m} 2$ sized seedling square, $10 \times 10 \mathrm{~m} 2$ sized sapling square and 20x20m2 sized square for trees (mature plants). There were 65 squares in total. The sociosystem samples in this research were the village officials, public figures, shamans, offerers, craftsmen, and the public in Tenganan Pegringsingan village. The methods applied in this research were (1) square method for ecosystem (vegetation) parameter. (2) Interview, questionnaire and observation for sociosystem parameter. The collected data were further analyzed descriptively. The results of the research showed that (1) of 46 useful plant species found in Bukit Kangin forest of Tenganan Pegringsingan, 29 of them were plant species that were utilized for religious ceremonies (Hinduism), meanwhile there were 17 plant species utilized for clothing, food, shelter, industry, medicine, and other household purposes. (2) The utilization of plant species for religious purposes was still in traditional method, in accordance with the sociocultural of the local community.
\end{abstract}

Keywords: biodiversity; socio cultural; hinduism; bali aga; tenganan pegringsingan.

$\begin{array}{lll}\text { History: } & \text { Publisher: Undiksha Press } \\ \text { Received } & : 8 \text { June } 2020 & \text { Licensed: This work is licensed under } \\ \text { Revised } & : 1 \text { July } 2020 & \\ \text { Accepted } & : \text { 26 July } 2020 & \text { Preative Commons Attribution 3.0 License } \\ \text { Published } & : \text { July } 2020 & \end{array}$

\section{Introduction}

Historical and archeological data about the current Bali Aga community is the result of the development of pre historical Austronesian people. The ancient Balinese who has the pre historical tradition is called Bali Aga or Bali Mula. In general, the Bali Aga people occupy mountainous areas such as Tenganan Pegringsingan, Terunyan, Sembiran and Sidatapa village (Astawa, Budiarsa, \& Simpen, 2019; Astawa, Budiarsa, Mbete, et al., 2019; Abioso \& Triyadi, 2017). On the one hand, Balinese people who came from East Java (Majapahit Kingdom) are called Bali Majaphit. The most striking difference between the people of Bali Mula/Bali Aga and the Balinese of Majapahit descent is at their funeral ceremony. The people of Bali Mula carry out their death ceremony by burying the corpse, which is called beya tanem. Meanwhile, the Majapahit Balinese carry out their death ceremony by cremating 
the dead body, that is called ngaben. The main physical difference in the village layouts between Bali Aga and Bali Majapahit is that Bali Aga has a wide enough open space that extends linearly from north to south, which divides the village into two parts. In the diametral position in the north end lies Pura Puseh (Vishnu worship temple), in the middle lies (Brahma worship temple), and in the southernmost lies Pura Dalem (Shiva worship temple). The public means of the infrastructures located in the middle of the village and the residential are on the lef and right sides of the village main road (Astawa, Budiarsa, Mbete, et al., 2019).

A fundamental emphasis on the culture of Bali Aga appears in the relation to the worship of ancestral spirits. This cultural aspect leaves many traces of the Pre-History era. Cultural products that show this characteristic can be found in the case of burial ceremony, in which various Grave Stones in the form of sarcophagi were used. This signifies that a very organized burial system was known by the Bali Aga people in the ancient times. Sarcophagus or other chests are found in several villages in Bali such as in Gilimanuk, Jembrana Regency, Marga Tengah Tabanan Regency, Taman Bali in Bangli Regency and so on (Astawa, Budiarsa, Mbete, et al., 2019). The recent developments lead to the refinement of the conception of belief in a higher power (super natural). There are several belief streams that are owned by the Balinese Aga. The concepts of worshiping certain deities for the people of Bali Aga includes religion of Bayu, Syambhu religion, Kala religion, Brahma religion, Vishnu religion, and Indra religion.

So far it is said that Balinese Aga people who adhere to certain religions are characterized by their forms of religious activities such as: followers of Bayu religion directing their people to worship the God of Bayu (God of the Winds) and at the time of death their bodies are placed on the cliffs they consider sacred. That belief is still found in Trunyan Village (Kintamani) (Astawa, Budiarsa, Mbete, et al., 2019). Another characteristic of the Bali Aga community such as the one in Tigawasa Village is that it does not carry out a cremation ceremony or Ngaben but rather a similar event called the Nangun ceremony. The concept of luan and teben is another characteristic of the Bali Aga culture as seen in the position of the Tenganan Pegringsingan village with the following characteristics: (1) Tenganan Pegringsingan village was built on the basis of steps, (2) the roads are covered with large stones, (3) sacred places built with steps, (4) buffalo raising for ceremony purposes (Astawa, Budiarsa, Mbete, et al., 2019; Abioso \& Triyadi, 2017).

According to (Nguyen et al., 2019) stated that useful plants in Indonesia based on their utilization can be grouped into several forms of use, including clothing, food, shelter, and household appliances, medicine, cosmetics, rigging and plaiting, as well as for social and religious activities. In addition, useful plants in Indonesia are also often used as ornamental plants, aromatics, coloring agents and as feed for livestock. Other experts categorizing the use of plants consist of clothing, shelter, food, medicine, household needs, and religious ceremonies. Plant parts that are used include roots, stems, leaves, flowers and fruit [7]. Among the various kinds of community knowledge about their plants utilization, some are magical, spiritual and ritual to them. One of the plant utilization is in the field of religious ceremonies. In various ethnicities, plants used in ceremonies vary according to the respective public knowledge. Plants are used in traditional ceremonies, mainly in connection with life cycle ceremonies. The plants used in traditional and religious rituals have characteristics as follow: seen from the nature of certain plants, especially flowers are often interpreted as feminity and used in naming ceremonies. In Javanese traditional wedding events plants are often associated with words of good value. There are some plants often used as herbs and preservatives of corpses (Nguyen et al., 2019; Pare et al., 2016).

The utilization of body symbol plants by the Bali Aga community has been used in funeral ceremonies in Bali Aga and Bali Majapahit except in Tenganan Pegringsingan 
village. Tenganan Pegringsingan village, which is a Bali Aga village, is not familiar with Ngaben ceremony as it is known by the Balinese in general. The funeral ceremony known in Tenganan Pegringsingan village is mendem ceremony, with a very simple (Hindu) religious ceremony. Thus the socio-culture (religiousity) in Tenganan Pegringsingan village is very unique and it still exists until now (Iskandar \& Iskandar, 2017). The contribution of forests to food security, among others, is as a genetic source for the continued development of food crop varieties, medicines, and provides a role as a protective environment and provides ecosystem services. Stated by (Mueller-Dombois \& Ellenberg, 1974) that edible forest plant species (fruit and / or leaves) found in the Gunung Tumpa community forest park were 23 species, including Pangium edule (Pangi), Dracontomelon dao (Rao), Dracontomelon mangiferum (Dahu), Mangifera foetida (Bacang), Arenga pinnata (Aren), Calamus sp (Rattan), Caryota mitis (Sayar), Alocasia sp. (Arum), Canarium asperum (Walnut forest), Capparis micracantha (Kencuran), Garcinia celebica (Tamarind acid), Dillenia ochreata (Simpor), Erythrina subumbrans (Dadap spare), Pithecellobium sp. (jengkol), Gnetum gnemon (melinjo), Ficus minahassae (Langusei), Pisonia umbellata (Kol banda), Pandanus sp. (Pandan), Ziziphus javanensis, Carallia brachiata (Kanis fruit), Pometia pinnata (Matoa), Grewia sp. (Diluwak), and Villebrunea rubescens (Ki nangsih).

Research on wild edible tree species (WETs) conducted in Ethiopia, said that there were 88 native edible wild plants, of which 52 species were WETs (Nguyen et al., 2019). Ethnobotany research on medicinal plants to reduce obesity has been carried out in Burkina Faso in the provinces of Seno (North) and Nayala (Northwest), found Sixty-one (61) plant species, belonging to thirty-one (31) families (Pare et al., 2016). Research conducted on the Baduy community, particularly the Outer Baduy community of the village of Kanekes, subdistrict of Leuwidamar, District of Lebak, Province of Banten, found at least 50 plant species representing 28 families have been used for those performing traditional rituals (Pare et al., 2016). Research conducted in Vietnam, by conducting interviews in the market of plants sold and used as medicinal plants, obtained 99 plant species belonging to 88 genera and 57 families, which are used to treat 61 different diseases. the most commonly used are leaves, stems and roots are most commonly used either fresh, dried or by decocting the dried parts in water (Nguyen et al., 2019). Research results by (Sumarlin et al., 2015) stated that based on the results of his interview with the community around Tembawang Forest, Aur Sampuk Village, Sengah Temila District, Landak Regency, there were 50 types of plants included in 35 plant families that could be used as food sources. Generally, from the types of food source plants, the parts used are fruits, leaves, seeds, and tubers. Whereas the way of processing it to be made into food is usually by being eaten directly and cooked.

In this study, it is necessary to further study the use of plants by the Bali Aga Tenganan Pegringsingan community. This study was conducted on the Bali Aga Tenganan Pegringsingan community based on the consideration that the local community still adheres firmly to the procession of the implementation of religious ceremonies (Hinduism). The ceremonies are in accordance with the original cultural customs which is not influenced by outside cultural interventions (Bali Majapahit). The purposes of this study were 1) to figure out the plants used in religious ceremonies (Hinduism) in accordance with the culture of Bali Aga Tenganan Pegringsingan village. 2) to figure out the process/manufacture of various the means needed in the ceremony related to the use of plants as a means of religious ceremonies (Hinduism) of the Bali Aga Tenganan Pegringsingan community. 


\section{Materials and Methods}

This research was conducted in Tenganan Pegeringsingan Village, Manggis District, Karangasem Regency, specifically in the Bukit Kangin forest. Geographically Tenganan Pegringsingan Village is located at coordinates $8^{\circ} 28$ ' 38 "S and $115^{\circ} 33$ '58" E. Map of the research location is presented in Figure 1.

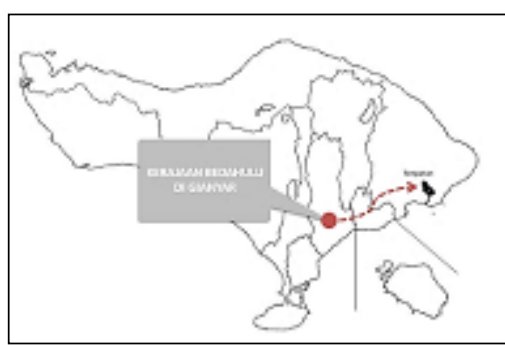

A

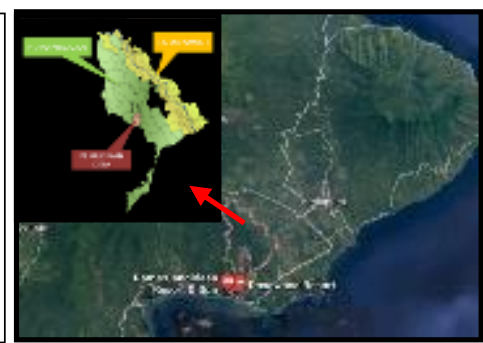

B

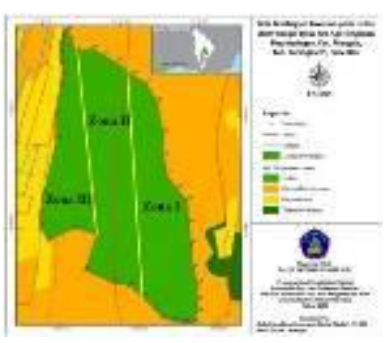

C

Figure 1. Research Location and Sampling Zone. (A) Bali Island. (B) Tenganan Pegringsingan Village. (C) Bukit Kangin Forest

This research was included to explorative (vegetation) research and sociosystem (community) research. The objects explored in this research were the plant species which were used as religious ceremonial means (Hinduism) by the community of Tenganan Pegringsingan village. Meanwhile, the sociosystem aspects included the methods/ways of making the religious ceremonial means and the products of the plants which traditionally produced by the local community/people.

The populations in this research included the aspects of ecosystem and sociosystem. The ecosystem aspects were the entire plant species in Bukit Kangin forest of Tenganan Pegringsingan village. The sociosystem aspects included the village officials, the village public figures, and the Tenganan Pegringsingan people. The samples of the ecosystem aspects were the entire useful plant species covered in square with size of $1 \mathrm{x} 1 \mathrm{~m} 2$ for seedling, $10 \times 10 \mathrm{~m} 2$ for sapling dan $20 \times 20 \mathrm{~m} 2$ for trees (mature plants). The total of the squares were 65 . The samples included the parts of the plants, i.e. roots, stems, leaves, flowers, fruits and seeds [12][18][19][10][11][12]. The plant species data collection was divided into two stages, they are preparation stage and implementation stage. Preparation Stage (1) Research Location Observation is observing of the location, its layout and the plant species in Bukit Kangin Forest of Tenganan Pegringsingan Village. (2) Research Permit from Tenganan Pegringsingan Official. (3) Preparing the research schedule with the source person. (4) Preparing The Tools and Materials as GPS, Compass, Environmental Thermometer, Soil tester, Anemometer, Hygrometer, Lux meter, Meter tape, Wooden peg, Raffia rope, and (5) Altimeter, Electric Scale, Blast Furnace, Digital Camera, Plastic Bag, Label Paper, Marker, and Data Recording Sheet. The implementation stage in collecting data on Bukit Kangin Forest, Tenganan Pegringsingan Village was with the following steps: (1) Divide the forest area into two zones. (2) Spread the transect line as a compass line. (3) Laying the squares on the compass line alternately. (4) The interval between the one square and the other was 10 meters each. (5) Data collection of plant species was carried out on tree habitus plant species with a square size of $20 \times 20 \mathrm{~m}$, sapling with a size of $10 \times 10 \mathrm{~m}$, and seedling with a size of $1 \mathrm{x} 1 \mathrm{~m}$, with a total of 65 squares. (See Figure 2). (6) Record the number of each plant species on each sample point and systemically measure the stem diameter. To make it easier to work on the field, the data obtained were recorded in a book that had been prepared with a work table which contained the local name of the plants, scientific name, number of species 
individuals and the stem circumference. (7) Measuring the research supporting parameters such as temperature, humidity, location height, light intensity, soil organic material, soil moisture and pH. (8) Documenting every plant species found. (9) Sampling plant species in the research field and collecting plant samples into the plastic bags which had been labeled as herbarium supplies. (10) Conduct laboratory observation by identifying the plant species through literature study.

The samples of the sociosystem aspects (community) in this research were the village officials, the village public figures, shamans, offerers, craftsmen and the other local people in Tenganan Pegringsingan village with total sample 27 persons. The paramaters measured in this research were based on: (1) the utilization of the useful plants existing in Bukit Kangin forest area by the people of Tenganan Pegringsingan village, (2) the socio cultural, that is the local people's socio cultural value in utilizing the useful plant species as religious ceremonial means (Hinduism) in which the data were collected through interview method [25].
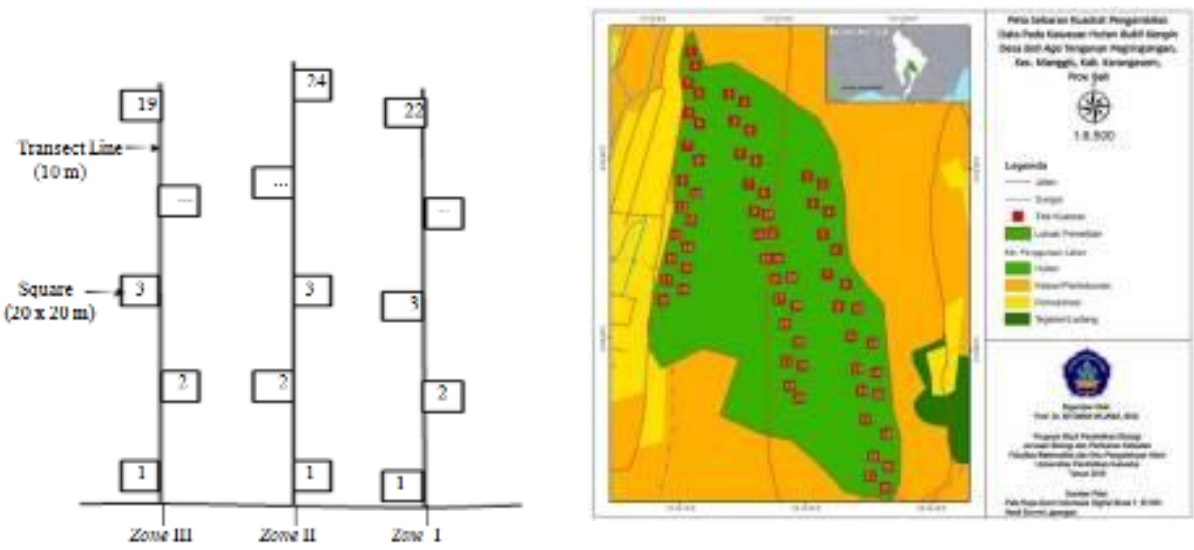

Figure 2. Schematic laying of squares (A).Laying map squared in the field (B)

The methods used in this research were square method was used for vegetation parameters. Meanwhile, the methods of interview, questionnaire, and obersvation were used for sociosystem parameters. In the interview, it was emphasized on the plants used by the local people for clothing, food, shelter, medicine, industrial and religious (Hinduism) purposes. From this utilization then further explored about the utilization of the plants organ included the roots, stems, leaves, flowers, fruits and seeds. Specifically, in depth interview about useful plant species for religious purposes was carried out to gain further information on how they were produced, utilized and the outcome products. The collected data were further analyzed descriptively.

\section{Results and Discussion}

The results of the plant species utilized by the community of Tenganan Pegringsingan village are shown in Table 1.

Table 1. The Utilization of Useful Plant Species and the Organs Used Based on Bali Aga Tenganan Pegringsingan Socio Cultural

\begin{tabular}{lllllllll}
\hline No & Species & \multicolumn{6}{c}{ Types of Utilization } & \\
\cline { 3 - 8 } & & Cl & Fd & Sh & Md & Rg & In \\
\hline 1 & Avocado (Persea americanda Mill.) & & + & & + & & \\
\hline 2 & Ambengan/Alang-alang & (Imperata & cylindrica & & & & + & + \\
\hline
\end{tabular}




\begin{tabular}{|c|c|c|c|c|c|c|c|}
\hline \multirow[t]{2}{*}{ No } & \multirow[t]{2}{*}{ Species } & \multicolumn{6}{|c|}{ Types of Utilization } \\
\hline & & Cl & Fd & Sh & Md & Rg & In \\
\hline & Beauv) & & & & & & \\
\hline 3 & Tamarind/Celagi (Taramindus indica Linn.) & & & & + & + & \\
\hline 4 & Ata (Lygordium circirnatum (Burm.) Sw.) & & & & & + & + \\
\hline 5 & Badung (Garcinia dulcis Kurs.) & & & & & + & \\
\hline 6 & Bambu Tali (Gigantochloa accer Kurz) & & & + & & + & \\
\hline 7 & Bayur (Pterespermum celebicum Miq.) & & & + & + & & \\
\hline 8 & Belalu (Hopea celebia Burck) & & & + & & & \\
\hline 9 & Belalu Bali (Hepea sp.) & & & + & & & \\
\hline 10 & Belimbing Buluh (Averrhoa bilimbi L.) & & + & & + & + & \\
\hline 11 & Banyan (Ficus benyamina L.) & & & & & + & \\
\hline 12 & Cempaka Putih (Michelia alba L.) & & & + & & + & \\
\hline 13 & Dauh (Dracontomelon mangiferum Bl.) & & & & & + & \\
\hline 14 & Durian (Durio zibetinus Murr.) & & + & + & & + & \\
\hline 15 & Enau (Arenga pinata Merr.) & & + & + & + & + & \\
\hline 16 & Gamongan (Zingiber aromaticum Valeton) & & & & + & + & \\
\hline 17 & Gegirang (Leea $s p)$ & & & & & + & \\
\hline 18 & Ilak-ilak (Amomum sp.) & & & & & + & \\
\hline 19 & Jambu Biji (Syzygium aqueum L.) & & + & & + & & \\
\hline 20 & Jangar Ulam (Syzygium polyanthum Miq.) & & & & + & & \\
\hline 21 & Jeruk Bali (Citrus maxima Merr.) & & + & & & + & \\
\hline 22 & Jeruk Lemo (Citrus amblycarpa Ochse) & & + & & & + & \\
\hline 23 & Juwet (Syzygium cumini(L.) Skeels) & & + & & + & & \\
\hline 24 & Cinnamon (Sauropus androgynus(L.) Merr.) & & & & + & & \\
\hline 25 & Coconut (Cocos nucifera L.) & & + & + & + & + & \\
\hline 26 & Candlenut (Aleurites moluccanus (L.) Willd) & + & & & & + & + \\
\hline 27 & Kepundung (Baccaurea racemosa Mull.Arg.) & + & + & + & & & \\
\hline 28 & Kerasi (Lantana camara L.) & & & & + & & \\
\hline 29 & Kutat (Planconia valida Blume) & & & + & & & \\
\hline 30 & Majegau (Dysoxylum densiflorum Miq.) & & & + & + & & \\
\hline 31 & Mango (Mangifera indica L.) & & + & + & & & \\
\hline 32 & Mangosteen (Carcinia mangostana L.) & & + & + & & & \\
\hline 33 & Pineapple (Ananas comosus (L.) Merr.) & & + & & & + & \\
\hline 34 & Jackfruit (Artocarpus heterophyllus Lamk) & & + & + & & + & \\
\hline 35 & Pakel (Mangifera foetida Lour.) & & & & & + & \\
\hline 36 & $\begin{array}{l}\text { Thorny Pandanus (Pandanus tectorius B.C. } \\
\text { Stone) }\end{array}$ & & & & & + & \\
\hline 37 & Pangi (Pangium eldute Reinw.) & & & & & + & \\
\hline 38 & Pinang (Areca catechu L.) & & & & + & + & \\
\hline 39 & Banana (Musa paradisiaca L.) & & + & & & + & \\
\hline 40 & Pule (Alstonia scholaris (L.) R.Br.) & & & & + & & \\
\hline 41 & Pulet (Urena lobata L.) & & & & + & & \\
\hline 42 & Rambutan (Nephelium lappaceum L.) & & + & & & + & \\
\hline 43 & Salak (Salacca endulis Reinw) & & + & & & + & \\
\hline 44 & Sukun (Artocarpus altilis (Parkinson) Fosberg) & & & & + & & \\
\hline 45 & Tabia Bun (Piper retrofractum Vahl.) & & & & & + & \\
\hline 46 & Talas/Keladi (Colocasia esculenta (L.) Schott) & & & & & + & \\
\hline
\end{tabular}


Informations: $\mathrm{Cl}=$ Clothing $\mathrm{Fd}=$ Food $\mathrm{Sh}=$ Shelter $\mathrm{Md}=$ Medicine $\mathrm{Rg}=$ Religious ceremony In = Industrial The illustrations in graphical form are presented in Figure 3.
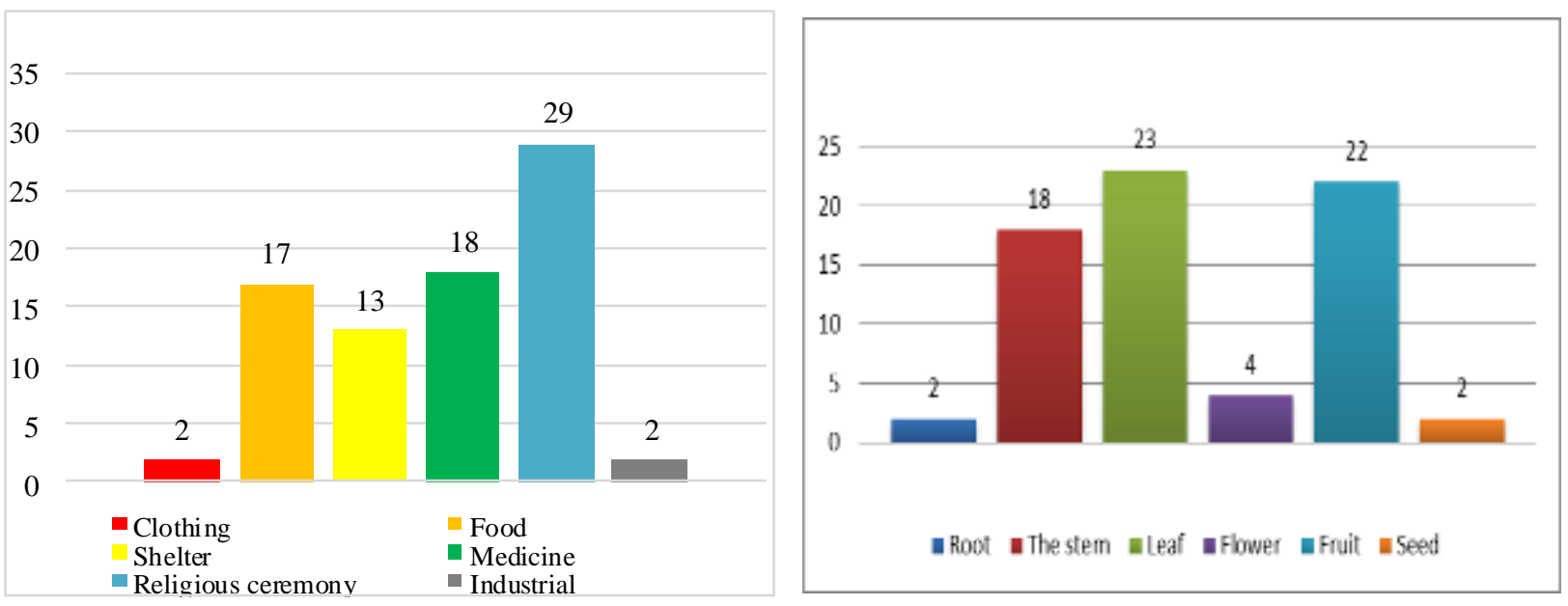

Figure 1. Utilızâtıon of Useful Plants (A) and Plant Parts Used (b) by Tenganan Pegringsingan Village Community

Based on Table 1 and Figure 3, it can be seen the major type of plant species utilization by the people of Tenganan Pegringsingan village which were oriented to the Bali Aga socio cultural was as a mean for religious ceremonies as much as 29 plant species $(35,5 \%)$. The plant species which were utilized in religious ceremonies were Ambengan/Alang-alang (Imperata cylindrica Beauv), Tamarind/ Celagi (Taramindus indica Linn), Ata (Lygordium circirnatum (Burm.) Sw.)), Badung (Garcinia dulcis Kurs.), Bambu Tali (Gigantochloa accer Kurz), Belimbing Buluh (Averrhoa bilimbi L), Banyan (Ficus benyamina L), Cempaka Putih (Michelia alba L), Dauh (Dracontomelon mangiferum Bl), Durian (Durio zibetinus Murr.), Enau (Arenga pinata Merr.), Gamongan (Zingiber aromatica Valeton), Gegirang (Leea Sp), Ilak-ilak (Amomum sp.), Jeruk Bali (Citrus maxima Merr.), Jeruk Lemo (Citrus amblycarpa Ochse), Coconut (Cocos nucifera L.), Candlenut (Aleurites moluccanus (L.) Willd), Kerasi (Lantana camara L), Majegau (Dysoxylum densiflorum Miq.), Pinapple (Ananas comosus (L.) Merr.), Jackfruit (Artocarpus heterophyllus Lamk), Pakel (Mangifera foetida Lour.), Thorny Pandanus (Pandanus tectorius B.C. Stone)), Pangi (Pangium eldute Reinw), Pinang (Areca catechu L.), Banana (Musa paradisiaca L), Pule (Alstonia scholaris(L.) R.Br.), Rambutan (Nephelium lappaceum L), Salak (Salacca endulis Reinw), and Talas/Keladi (Colocasia esculenta(L.) Schott)).

The other plants were used as medicine $(21,6 \%)$, including Alpukat (Persea americanda Mill.), Ambengan/Alang-alang (Imperata cylindrica Beauv), Asem/ Celagi (Taramindus indica Linn), Bayur (Pterespermum celebicum Miq), Belimbing Buluh (Averrhoa carambola L.), Enau (Arenga pinata Merr.), Gamongan (Zingiber aromatica Valeton), Jambu Biji (Syzygium aqueum L), Jangar Ulam (Syzygium polyanthum Miq), Juwet (Syzygium cumini (L.) Skeels)), Cinnamon (Sauropus androgynu (L.) Merr s), Coconut (Cocos nucifera L.), Kerasi (Lantana camara L), Majegau (Dysoxylum densiflorum Miq), Pinang (Areca catechu L.), Pule (Alstonia scholaris(L.) R.Br.), Pulet (Urena lobata L), and Sukun (Artocarpus altilis(Parkinson) Fosberg). The plants utilized for food were Avocado (Persea americanda Mill.), Belimbing Buluh (Averrhoa bilimbi), Durian (Durio zibetinus Murr.), Enau (Arenga pinata Merr.), Jambu Biji (Syzygium aqueum L), Jeruk Bali (Citrus maxima Merr.), Jeruk Lemo (Citrus amblycarpa Merr.), Juwet (Syzygium cumini (L.) Skeels), Kelapa (Cocos nucifera L.), Kepundung (Baccaurea racemosa Mull.Arg.), Mango (Mangifera indica L), 
Mangosteen (Carcinia mangostana L.), Pinapple (Ananas comosus (L.) Merr.), Jackfruit (Artocarpus heterophyllus Lamk), Bananas (Musa paradisiaca L), Rambutan (Nephelium lappaceum L), and Salak (Salacca endulis Reinw).

The plants for shelter (18,9\%), including Belalu (Hopea celebia Burck), Belalu Bali (Hepea sp.), Cempaka Putih (Michelia alba L), Durian (Durio zibetinus Murr.), Enau (Arenga pinata Merr.), Coconut (Cocos nucifera L.), Kepundung (Baccaurea racemosa Mull.Arg), Mango (Mangifera indica L), Mangosteen (Carcinia mangostana L.), Pinapple (Ananas comosus (L.) Merr.), Jacfruit (Artocarpus heterophyllus Lamk), Rambutan (Nephelium lappaceum L), Banana (Musa paradisiaca L) and Salak (Salacca endulis Reinw). The plants used for clothing $(2,4 \%)$ including Candlenuts (Aleurites moluccanus (L.) Willd) and Kepundung (Baccaurea racemosa Mull.Arg). Meawhile, the plants which were utilized in industry $(2,4 \%)$ including Ata (Lygordium circirnatum (Burm.) Sw ) and Candlenuts (Aleurites moluccanus (L.) Willd).

Associated with the use of plants as a means of religious ceremonies (Hinduism), the people of Tenganan Pegeringsinan village still maintain the customs and traditions handed down by their ancestors. This can be seen by the ongoing religious ceremonies in the village and their authenticity until they become a characteristic of the village. One of the religious ceremonies that still exists in the village of Tenganan Pegeringsingan is Mekare-kare (Pandanus War) which is carried out at the time of sasih kalima according to the local calendar. A lot of plants in Bukit Kangin forest are used in the preparation of Mekare-kare. Many ceremonial means used by the local community have not been revealed to the surface or are unknown by the community outside the village of Tenganan Pegringsingan. Here are the types of plants used for religious ceremonies (Hinduism) by the community of Tenganan Pegeringsingan village, presented in Table 2 and Table 3.

Table 2. Data of Plant Species for Religious Ceremonial Means (Hinduism) by the People of Tenganan Pegringsingan Village

\begin{tabular}{|c|c|c|c|}
\hline $\begin{array}{l}\mathbf{N} \\
\mathbf{O}\end{array}$ & SPECIES & $\begin{array}{l}\mathbf{N} \\
\mathbf{O}\end{array}$ & SPECIES \\
\hline 1 & $\begin{array}{l}\text { Ambengan/Alang-alang } \\
\text { cylindrica Beauv) }\end{array}$ & 16 & $\begin{array}{l}\text { Jeruk Lemo (Citrus amblycarpa } \\
\text { Ochse) }\end{array}$ \\
\hline 2 & $\begin{array}{l}\text { Tamarind/Celagi (Taramindus indica } \\
\text { Linn.) }\end{array}$ & 17 & Coconut (Cocos nucifera L.) \\
\hline 3 & $\begin{array}{l}\text { Ata (Lygordium circirnatum (Burm.) } \\
\text { Sw.) }\end{array}$ & 18 & $\begin{array}{l}\text { Candlenut (Aleurites moluccanus } \\
\text { (L.) Willd) }\end{array}$ \\
\hline 4 & Badung (Garcinia dulcis Kurs.) & 19 & $\begin{array}{l}\text { Pineapple (Ananas comosus (L.) } \\
\text { Merr.) }\end{array}$ \\
\hline 5 & Bambu Tali (Gigantochloa accer Kurz) & 20 & $\begin{array}{ll}\text { Jackfruit } & \text { (Artocarpus } \\
\text { heterophyllus Lamk) } & \end{array}$ \\
\hline 6 & Belimbing Buluh (Averrhoa bilimbi L.) & 21 & Pakel (Mangifera foetida Lour.) \\
\hline 7 & Banyan (Ficus benyamina L.) & 22 & $\begin{array}{l}\text { Thorny Pandanus (Pandanus } \\
\text { tectorius B.C. Stone) }\end{array}$ \\
\hline 8 & Cempaka Putih (Michelia alba L.) & 23 & Pangi (Pangium eldute Reinw.) \\
\hline 9 & Dauh (Dracontomelon mangiferum Bl.) & 24 & Pinang (Areca catechu L.) \\
\hline 10 & Durian (Durio zibetinus Murr.) & 25 & Banana (Musa paradisiaca L.) \\
\hline 11 & Enau (Arenga pinata Merr.) & 26 & $\begin{array}{l}\text { Rambutan (Nephelium lappaceum } \\
\text { L.) }\end{array}$ \\
\hline 12 & $\begin{array}{l}\text { Gamongan (Zingiber } \\
\text { Valeton) }\end{array}$ & 27 & Salak (Salacca endulis Reinw) \\
\hline 13 & Gegirang (Leea sp) & 28 & (Piper retrofractum \\
\hline
\end{tabular}




\begin{tabular}{lll}
\hline Ilak-ilak (Amomum sp.) & $29 \begin{array}{l}\text { Vahl.) } \\
\text { Talas/Keladi (Colocasia esculenta } \\
\text { (L.) Schott) }\end{array}$ \\
\hline
\end{tabular}

15 Jeruk Bali (Citrus maxima Merr.)

Table 3. Examples of Utilization and How to Use of the Useful Plant Species for Religious Ceremonial Means (Hinduism) by the People of Tenganan Pegringsingan Village

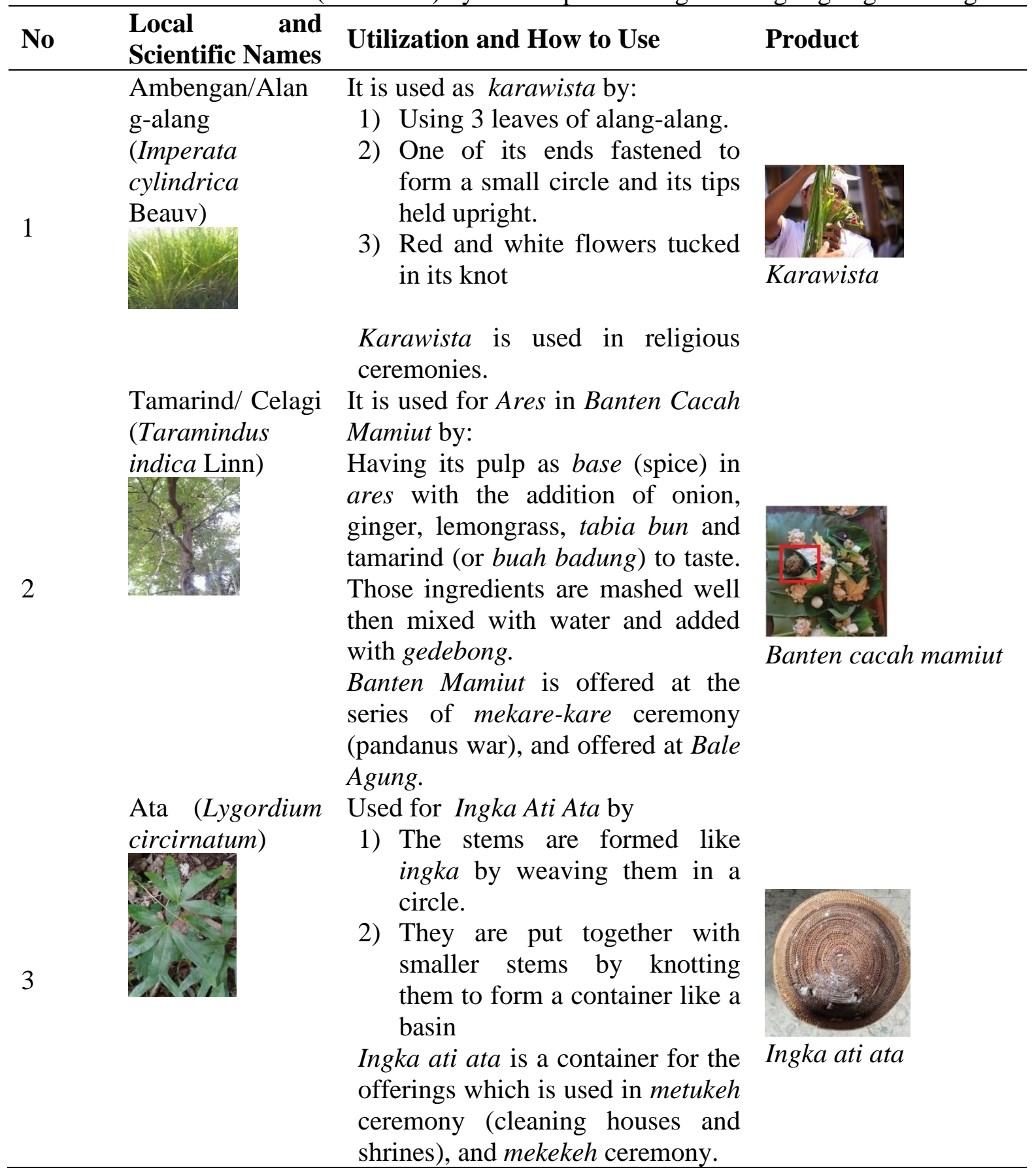




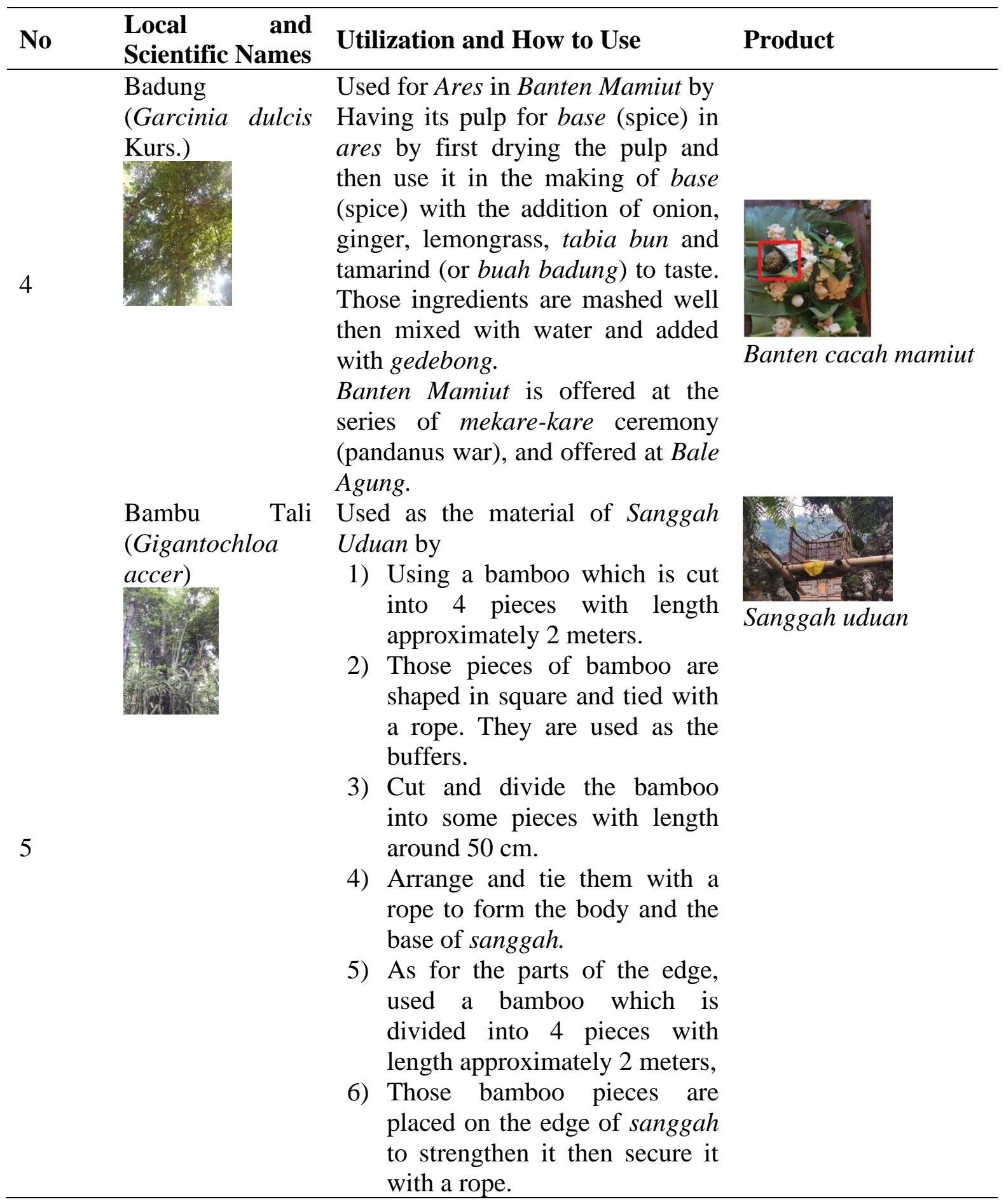

Of the 46 useful plant species in Bukit Kangin forest, there were 29 plant species that were utilized in religious ceremonies, and the other 17 plant species were used for other purposes such as clothing, food, shelter, industry and household purposes. Based on the utilization, the useful plant species in Indonesia can be grouped into some types of usefulness, they are for clothing materials, food, shelter, household aplliances, medicine, cosmetics, ropes and netting, also for social and religious activities (Barbour, M.G., J. H. Burk., W. D. Pits. 1987). In Tenganan Pegringsingan village, the local people utilize their forest products for clothing, food, shelter, medicine, religious ceremonial means and insdustial purposes. Based on the interview with Ibu Komang Handayani (Private Interview, 2019) There are various useful plant species mostly used as religious ceremonial means by 
the people of Tenganan Pegringsingan village such as Bambu Tali (Gigantochloa accer), Enau (Arenga pinata Merr.), Gegirang (Leea angulata), Kelapa (Cocos nucifera L.), Pinang (Areca catechu L.), and Banana (Musa paradisiaca).

The stem of Bambu Tali (Gigantochloa accer) is used as sanggah uduan and pepaya by the local people. Sanggah uduan is used in sasih kasa as a place to put the offerings (banten). Meawhile pepaya (coffin) is used in death ceremony. The bamboo stem used as cemeng, penimpug and prayascita durmanggala. The people of Tenganan Pegringsingan Village use the leaves of Enau (Arenga pinata Merr.) as coblong and its fruit as subeng. Coblong is a complement in the local traditional ceremonies. Meanwhile, subeng is worn by 1 month old to 2 month old baby as ear peircings. Generally the old leaves of Enau (Arenga pinata Merr.) or ron are utilized by Hindus as jejahitan, such as lamak, gantung gantungan, and sampian. Meanwhile its ripe fruits or bluluk are used for offerings which are placed behind a dead body along with the other offerings (Wijana \& Setiawan, 2017).

The stems and leaves of Gegirang (Leea angulata) are utilized for bale gegirang/bade and sanggah gegirang by the local people. Bale gegirang is used in ngerorasin ceremony (12 days after death ceremony). Meanwhile sanggah gegirang is used in religious ceremonies during sasih kalima. According to [30] Hindu people in Bali generally use gegirang (Leea angulata) fruits only for peangkat-angkat bebangkit and its thorn for ngelukat/ngeruat. Coconuts, by the people of Tenganan, are used for urab in banten cacahan and for plugantung in banten pabuaci. Its leaves are used for sengkui and paku pipid in sanggah gedebong. Urab is used in cacah mamiut which is offered in the series of pandanus war ceremony. Plugantung is offered in the ceremonies held sasih kalima. Sengkui is a complement of pemuja offerings. Coconuts (Cocos nucifera L.) have huge benefits for the community, especially the Balinese. Starting from the roots to its fruits can be utilized by the community. Its leaves are widely used for jejahitan, its fruits are used as the offering complements such as for daksina. Meanwhile, its stems are used as building materials and its roots as medicine.

The leaves of Pinang (Areca catechu L.), by the people of Tenganan Pegringsingan village, are used for lungga-lunggaan sasih kapat and the nuts are used for bunga base. Bunga base are offered at the change of sasih and placed at bale agung. Pinang (Areca catechu L.), by the people of Balinese Hindu, generally use the nut pods (upih) in the performance of ngelungah ceremony (ceremony for dead baby) In utilizing bananas (Musa paradisiaca) as a complement of religious ceremonies, the people of Tenganan Pegringsingan use the stems for Sanggah Gedebong and Nanjuk in the ceremony of Muran Desa. Banana leaves are used for Cacaran, Sanggah Gedebong, Ceniga, and Nanjuk in the ceremony of Muran Desa. Meanwhile its fruits are used as a complent in Cacaran offering. Banana (Musa paradisiaca) has huge benefirs in various ceremonies. Its fruits are generally used in the ceremonies. The fruits can be used as a complement in a ceremony such as raka-raka.

The other useful plants use as a religious ceremony complement are Alang-alang (Imperata cylindrica Beauv), Asem Jawa (Taramindus indica L.), Ata (Lygordium circirnatum), Badung (Garcinia dulcis Kurs.), Belimbing Buluh (Averrhoa bilimbi), Banyan (Ficus benyamina), Cempaka Putih (Michelia alba), Dauh (Dracontomelon mangiferum), Durian (Durio zibetinus Murr.), Gamongan (Zingiber aromatica), Ilak-ilak (Amomum sp.), Jeruk Bali (Citrus maxima Merr.), Jeruk Lemo (Citrus amblycarpa), Coconut (Cocos nucifera L.), Candlenut (Aleurites moluccanus (L.) Willd), Pinapple (Ananas comosus (L.) Merr.), Jackfruit (Artocarpus heterophyllus Lamk), Pakel (Mangifera foetida Lour.), Thorny Pandanus (Pandanus tectorius), Pangi (Pangium eldute), Pinang (Areca catechu L.), Rambutan (Nephelium lappaceum), Salak (Salacca endulis Reinw), Tabia Bun (Piper retrofractum Vahl.), Talas/Keladi (Colocasia esculenta) (Dejene et al., 2020; Wijana, 2014). 


\section{Conclusion}

The conclusion of this research are: (1) Out of 46 useful plant species in Bukit Kangin forest of Tenganan Pegringsingan village, there were 29 plant species that were utilized for religious ceremony purposes (Hinduism), meanwhile the other 17 plant species are used for clothing, food, shelter, industry, medicine and household appliances purposes. (2) The way of the plant species utilization for religious ceremony puposes is still in traditional way, in accordance with the local community cultures. From those conclusions, here are several recommendations (1) The government together with the local community to keep maintaining and preserving the culture and the plant species; and (2) Creative tourism can be developed by utilizing the local culture and the useful plant species as tourist attractions.

\section{References}

Abioso, W. S., \& Triyadi, S. (2017). The Behavior - Milieu Synomorphy of Communal Space in Desa Adat Tenganan Pegringsingan Bali Indonesia. International Journal of Architecture, Arts and Applications, 3(2), 11-20. https://doi.org/10.11648/j.ijaaa.20170302.11

Astawa, I. G., Budiarsa, M., Mbete, A., \& Simpen, I. W. (2019). The Interpretation of Ecological Preservation in the Awig-awig (Customary Law) Text of Tenganan Pegringsingan Village: Positive Discourse Analysis. E-Journal of Lingusitics, 13(2), 5671. https://doi.org/DOI.10.24843/eJL.2018.v.12.i01.p.03

Astawa, I. G., Budiarsa, M., \& Simpen, I. W. (2019). The Representation of The Tri Hita Karana Ecosophy in The Awig-awig (Customary Law) Text of Tenganan Pegringsingan Village: Critical Ecolinguistics Perspective. Journal of Language Teaching and Research, 10(2), 396-401. https://doi.org/10.17507/jltr.1002.23

Barbour, M.G., J. H. Burk., W. D. Pits. 1987. Terrestrial Plant Ecology. Inc. California: The Benjamin/cummings. California: Publishing Company

Dejene, T., Agamy, M. S., Agúndez, D., \& Martin-Pinto, P. (2020). Ethnobotanical survey of wild edible fruit tree species in lowland areas of Ethiopia. Forests, 11(2). https://doi.org/10.3390/f11020177

Iskandar, J., \& Iskandar, B. S. (2017). Various Plants of Traditional Rituals: Ethnobotanical Research Among The Baduy Community. Biosaintifika: Journal of Biology \& Biology Education, 9(1), 114-125. https://doi.org/10.15294/biosaintifika.v9i1.8117

Nguyen, T. S., Xia, N. H., Van Chu, T., \& Van Sam, H. (2019). Ethnobotanical study on medicinal plants in traditional markets of son la province, Vietnam. Forest and Society, 3(2), 171-192. https://doi.org/10.24259/fs.v3i2.6005

Mueller-Dombois \& Ellenberg. 1974.Aims and Methods of Vegetation Ecology. Sanfransisco : W. H. Freeman and Company

Pare, D., Hilou, A., Ouedraogo, N., \& Guenne, S. (2016). Ethnobotanical Study of Medicinal Plants Used as Anti-Obesity Remedies in the Nomad and Hunter Communities of Burkina Faso. Medicines, 3(2). https://doi.org/10.3390/medicines3020009

Sumarlin, D., Dirhamsyah, M., \& Hafiz, A. (2015). Identifikasi tumbuhan sumber pangan di hutan tembawang desa aur sampuk kecamatan sengah temila kabupaten landak. Jurnal Hutan Lestari, 4(1), 32-39. http://jurnal.untan.ac.id/index.php/jmfkh/article/view/14481 
Wijana, N. (2014). Analisis Komposisi Dan Keanekaragaman Spesies Tumbuhan Di Hutan Desa Bali Aga Tigawasa, Buleleng - Bali. JST (Jurnal Sains Dan Teknologi), 3(1), 288299. https://doi.org/10.23887/jst-undiksha.v3i1.2907

Wijana, N., \& Setiawan, I. G. A. N. (2017). Plant Species Mapping and Density in the Village Forest of Penglipuran, Bangli, Bali, Indonesia and Its Use in Learning Media. Journal of Natural Science and Engineering, 1(3), 80-91. https://doi.org/http://dx.doi.org/10.23887/ijnse.v1i3.12937 